\title{
Production of Corn Nut Snacks from Corn Kernels
}

\author{
Hayat Hashem Abd-Elsattar, Sohair Taher El-Hadidie, Maha Mounier Tawfik
}

Food Technology Research Institute of Agriculture Research Centre, Giza, Egypt

\section{Email address:}

mahalouz@yahoo.com (M. M. Tawfik)

\section{To cite this article:}

Hayat Hashem Abd-Elsattar, Sohair Taher El-Hadidie, Maha Mounier Tawfik. Production of Corn Nut Snacks from Corn Kernels. International Journal of Nutrition and Food Sciences. Vol. 5, No. 6, 2016, pp. 413-421. doi: 10.11648/j.ijnfs.20160506.17

Received: September 7, 2016; Accepted: September 26, 2016; Published: November 9, 2016

\begin{abstract}
The present study aimed to investigate the possibility of preparing acceptable snacks with better nutritional content and sensory attributes from corn kernels. The corn kernels were subjected to different methods of processing i.e. boiling, autoclaving, microwave cooking and germination. The corn nut snack products were evaluated for its nutritional composition and nutritive value. The data revealed that, frying methods was the best sensory attributes than roasting ones. It could be found that all chemical composition decreased due to all processing methods except that of fat which may be due to adding it during processing. Minerals content varied according to the methods of processing. All processed corn nuts resulted in decreasing amylose and increase amylopectin. According to peroxide value, the deteriorates beginning after 10 weeks of storage which in parallel with acid value.
\end{abstract}

Keywords: Corn Nut, Microwave, Roasting, Frying, Sensory Evaluation, Peroxide and Acid Values

\section{Introduction}

In recent times, it is becoming increasingly necessary to produce highly acceptable snack foods with high nutritional quality that are yet affordable by potential consumers. Cereal grains are predominantly used for the production of different snack foods some of which may be eaten mainly to prevent hunger before main meals or just as relishes. Corn (Zea mays L.) is the most widely grown cereal crop, along with wheat and rice, in the world. More than half of an annual corn production is used as livestock feed and as industrial materials, and the remainder is used as a foodstuff [1]. In 2008, over 750 million metric tons were produced, with the United States, European Union, China, Brazil, Mexico, and India being the world's leading suppliers [2]. Kernels can be consumed off the cob, parched, boiled, fried, roasted, ground, and fermented for use in breads, porridges, gruel, cakes, and alcoholic beverages. Further processing leads to its use as food thickeners, sweeteners, oils, and no consumables [3]. The consumption rate of maize, especially boiled and roasted maize, has been on the increase particularly in the Southern part of Nigeria during every annual maize harvest season which is usually between the months April and September. Maize, providing an estimated $15 \%$ of the world's protein and $20 \%$ of the world's calories [4]. Maize kernels can vary in color (for example, white, yellow, orange, red, and black) [5].The protein content of maize is very low constituting only about $9-12 \%$ when compared with other grains. It however known to be rich in methionine, cystine and some sulphur containing amino acids [6]. Compared with the fat content of other foods such as sunflower seeds $(51 \mathrm{~g} / 100 \mathrm{~g})$ or soybeans $(20 \mathrm{~g} / 100 \mathrm{~g})$, whole kernel maize is relatively low in fat (5 $\mathrm{g} / 100 \mathrm{~g}$ ) [7]. Food processing technologies can contribute also to the alleviation of micronutrient deficiencies. One of these, germination which is widely used in legumes and cereals to increase their palatability and nutritional value, particularly through the breakdown of certain anti nutrients, such as phytate and protease inhibitors [8], [9], [10]. Process operations that reduce the level of ant nutritional factors and that minimize the losses of micronutrients are of interest. Mechanical, thermal or biological processes have the potential to improve the nutrient avail ability in foods [11], [12]. Wet processing including soaking, germination and fermentation leads to a reduction in phytic acid and increases of the minerals solubility in foods and could thus improve bioavailability of minerals in cereals and legumes [8].

The nutritional value of processed food is rarely better than that of the raw food material, although there are some beneficial effects of processing (e.g. the destruction of trypsin inhibitor in legumes and the liberation of bound niacin in cereals). During processing, nutrients are lost 
because they leached by water at some stage in the processing [13]. Different methods of processing, as boiling, cooking, roasting and sprouting, have effects on the nutritional quality of Kersting's groundnut seed flours [14]. In food processing and cooking, corn kernels have been mainly treated germination, by steaming, boiling, grilling, puffing or milling, and then consumed directly or as the second processing products including cornmeal, starch, oil, sugar and ethanol [1]. Microwave energy has been used since the early 1960s' for several food processes such as thawing, drying, baking and cooking [15]. It has been found to be safe; there was no toxicity or adverse effects on the diets containing meat and legumes cooked by microwave compared with conventionally cooked ones or diets. In addition, there is no risk from the radiation used for microwave cooking on health [16].

The aim of this study is the possibility of producing acceptable snack, with better nutritional content and sensory quality from corn kernels. The corn kernels were subjected to different methods of processing i,e., boiling, autoclaving, microwave cooking and germination in order to evaluate the nutritional composition and nutritive value of the processed corn snacks.

\section{Materials and Method}

\subsection{Materials}

Yellow Corn kernels (Commercial Verity), Sun flower oil, ketchup powder flavor and local corn nuts (as a control) were purchased from the local market at Giza Governorate, Egypt. All chemicals used were analytical grade.

\subsection{Methods}

\subsubsection{Technological Treatments of Corn Kernels}

Corn kernels were sorted, cleaned from impurities, washed, and then subjected to some technological treatments before preparing of corn snack as illustrated in Fig. 1. The corn kernels were soaked in water for $20 \mathrm{~h}$ with a ratio $1: 5 \mathrm{w} / \mathrm{v}$ and the soaked water changed twice. At the end of soaking period, the kernels were rinsed twice with distilled water. For sprouting, soaked kernels were kept between thick layers of cotton cloth and placed in plastic boxes allowed to germinate in the dark at room temperature for $72 \mathrm{~h}$.For cooking, rinsed kernels were blanched until they became soft when felt between the fingers for a period of $(90 \mathrm{~min})$ at $70^{\circ} \mathrm{C}$. For roasting, rinsed kernels was oven-dried in a convection (Memmert, Cambridge, UK) at 100 Ć for $30 \mathrm{~min}$. For frying, rinsed kernels deeply fried at $180^{\circ} \mathrm{C}$ in sunflower oil to produce a golden-yellow, hard - textured, low-moisture product [17]. Autoclaving, rinsed soaked kernels were autoclaved at $15 \mathrm{lb}$ pressure $\left(121^{\circ} \mathrm{C}\right)$ in tap water $(1: 10, \mathrm{w} / \mathrm{v})$ until $50 \%$ of the kernels were soft when felt between the fingers (35 min).Microwave cooking, rinsed soaked kernels were placed in a Birex pot with tap water $(1: 10, \mathrm{w} / \mathrm{v})$, then cooked in a microwave oven (Goldstar, Model ER-50540, $2450 \mathrm{MHz}$, Egypt) on high for $15 \mathrm{~min}$ (about 50\% of the kernels were soft when felt between the fingers) [18]. Samples from soaking, sprouting, cooking, autoclaving, under vacuum and microwaving cooking treatments were allowed to roasting or frying to produce 20 treatments, all treatments mixed well with the flavor then subjected to panel test to select the best ones and stored at room temperature $25 \pm^{\circ} \mathrm{C}$ over storage period (10 weeks) until analysis.

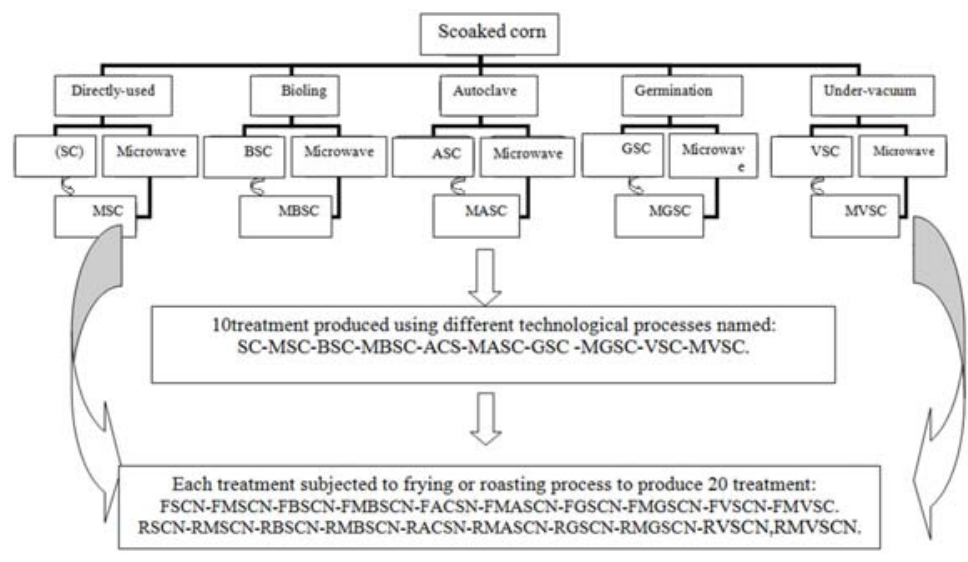

Fig. 1. Different technological processes of corn nut snack products.

Where:

FSCN: Fried Soaked Corn nut, FMSCN: Fried Micro waved Soaked Corn nut, FBSCN: Fried Boiled Soaked Corn nut, FMBSCN: Fried Micro waved Boiled Soaked Corn nut, FASCN: Fried Autoclaved Soaked Corn nut, FMASC: Fried Micro waved Autoclaved Soaked Corn nut, FGSCN: Fried Germination Soaked Corn nut, FMGSCN: Fried Micro waved Germination Soaked Corn nut, FUSCN: Fried Under vacuum Soaked Corn, FMUSCN: Fried Micro waved vacuum Soaked Corn nut.

RSCN: Roasted Soaked Corn nut RMSCN: Roasted Micro waved Soaked Corn nut RBSCN: Roasted Boiled Soaked Corn nut RMBSCN: Roasted Micro waved Boiled Soaked Corn nut, RASCN: Roasted Autoclaved Soaked Corn nut RMASCN: Roasted Micro waved Autoclaved Soaked Corn nut, RGSCN: Roasted Germination Soaked Corn nut, RMGSCN: Roasted Micro waved Germination Soaked Corn nut, RUSCN: Roasted Under vacuum Soaked Corn nut, 
RMUSCN: Roasted Micro waved vacuum Soaked Corn nut,

\subsubsection{Sensory Evaluation}

Sensory evaluation (taste, aroma, color, appearance, mouth feel (crispness) and overall acceptability) described by [19]. Twenty panelists (13 female and 7 male, their ages between 25 to 55 years) from the staff and workers of Food Technology Research Institute, Agricultural Research Center, Giza- Egypt evaluated the sensory attributes of different corn snack compared with the control (local corn nut). These characteristics using the 9-point hedonic scale) as follow: 9=like extremely, 8=like very much, 7=like moderately, $6=$ like slightly, $5=$ neither like nor dislike $4=$ dislike slightly, $3=$ dislike moderately, $2=$ dislike very much, $1=$ dislike

\subsubsection{Determination of Proximate Composition}

Moisture, protein, fat, crude fiber and ash contents of the raw corn kernels, commercial corn nuts

(As a control) and all treatments were determined according to the methods of [20]. Total carbohydrate was calculated by difference. The energy, were calculated by the formula of [21] as follows: Energy $(\mathrm{Kcal})=\{$ Fat $\times 9+$ Protein $\mathrm{x} 4$ +Total carbohydrate x 4\}

\subsubsection{Determination of Amylase Amylopectin Contents}

Amylose was determined using the method outlined by [22]. Amylose content was expressed as $\mathrm{g} / 100 \mathrm{~g}$ dwt. Amylopectin was calculated by difference using following

formula: (Amylopectin $(\%)=100 \%$ - amylose \%).

\subsubsection{Determination of Minerals}

Minerals content were determined by ashing methods as outlined in [20]. Perkin Elmer (Model 3300, USA) Atomic Absorption Spectrophotometer was used to determine zinc, iron, calcium, potassium, sodium and magnesium contents

\subsubsection{Determination of Peroxide Value (PV)}

Peroxide value of the extracted oil from the produced snacks was determined at intervals storage period (from zero time up to 10 weeks at room temperature $25 \pm 2^{\circ} \mathrm{C}$ ) according to the methods described by [23].

\subsubsection{Determination of Acid Value}

Acid value of the extracted oil from the produced snacks was determined at intervals storage period (from zero time up to 10 weeks at room temperature $25 \pm 2{ }^{\circ} \mathrm{C}$ ) according to the methods described by [24].

\subsection{Statistical Analysis}

Form the obtained data, mean values and standard deviation are reported. The data obtained were subjected to one-way analysis of variance (ANOVA) and least significant difference (LSD) at $\mathrm{p}<0.05$.

\section{Results and Discussion}

Table 1. Sensory evaluation of commercial corn nut and corn nuts products which produced by different technological processes.

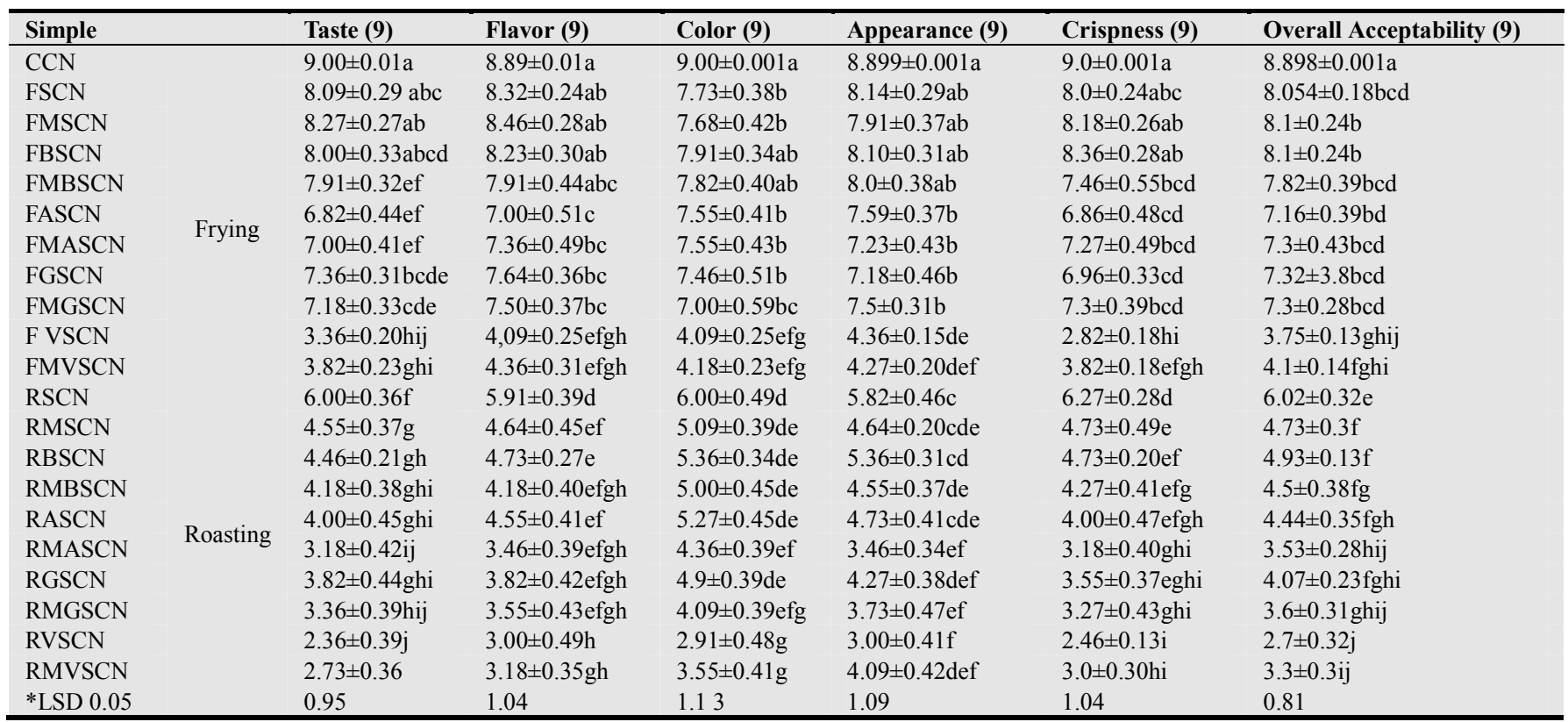

*Values in the same raw followed by different letters indicate signifcant difference at $\mathrm{p} \leq 0.05$

Where:

CCN: Commercial corn nut (as a control) FSCN: Fried Soaked Corn, FMSCN: Fried Micro waved Soaked Corn, FBSCN: Fried Boiled Soaked Corn, FMBSCN: Fried Micro waved Boiled Soaked Corn, FASCN: Fried Autoclaved Soaked Corn, FMASC: Fried Micro waved Autoclaved Soaked Corn, FGSCN: Fried Germination Soaked Corn, FMGSCN: Fried Micro waved Germination Soaked Corn, FVSCN: fried Under vacuum Soaked Corn, FMVSCN: Fried Micro waved vacuum Soaked Corn, RSCN: Roasted Soaked Corn

RMSCN: Roasted Micro waved Soaked Corn RBSCN: Roasted Boiled Soaked Corn RMBSCN: Roasted Micro waved Boiled Soaked Corn, RASC: Roasted Autoclaved Soaked Corn RMASCN: Roasted Micro waved Autoclaved Soaked Corn, RGSCN: Roasted Germination Soaked Corn, RMGSCN: Roasted Micro waved Germination Soaked Corn, RVSCN: Roasted Under vacuum Soaked Corn, RMVSCN: Roasted Micro waved vacuum Soaked Corn. 
Table 1 showed the sensory evaluation of 20 corn nuts produced by different technological processes represent in table (1). All treatments were subjected to sensory evaluation by20 Judged personal of food technology Institute to evaluate taste, flavor, color, appearance, crispness and overall acceptability compared to commercial corn nuts (as a control). It could be mentioned that treatments which had a mean score value less than 5 was refused and vs. versa, the acceptable treatments had a mean score value more than (5).From results it could mentioned that all fried corn nut products had a mean score values over (5) with a range from $6.82 \pm 0.44$ to $8.27 \pm 0.27,7.00 \pm 0.44$ to $8.46 \pm 0.28,7.00 \pm$ 0.59 to $7.91 \pm 0.34,7.18 \pm 0.46$ to $8.14 \pm 0.29$ and $6.86 \pm 0.48$ to $8.36 \pm 0.28$ in terms taste, flavor, color, appearance and crispness except (FVSCN and FMVSCN) which recorded a mean score value $3.36 \pm 0.20$ and $3.82 \pm 0.23,4.09 \pm 0.25$ and $4.36 \pm 0.31,4.09 \pm 0.25$ and $4.18 \pm 0.23,4.36 \pm 0.15$ and $4.27 \pm 0.20$ and $2.82 \pm 0.18$ and $3.82 \pm 0.28$ in the same terms respectively. Compared to the roasted corn nut products, all roasted corn nut products had a mean score values less than (5) non acceptable treatments except (RSCN) which recorded a mean score value $(6 \pm 0.36,5.91 \pm 0.39,6 \pm$ $0.49,5.82 \pm 0.46$ and $6.27 \pm 0.28$ for taste, flavor, color, appearance and crispness. from the results it could noticed that, among all acceptable treatments in terms taste and crispiness treatments (FMSCN.FSCN,FBSCN) were the most preferred treatments which were significantly differences from (FGSCN,FMGSCN,RSCN) compared to the control (commercial corn nut $\mathrm{CCN}$ ). With respect to color, non significant differences among each other's while RSCN was the least preferred treatment. In general, from 20 treatment were subjected to sensory evaluation, only 9 acceptable treatments $(8$ treatment resulting from frying and one treatment from roasting processes) were recorded a mean score values over (5) regarding to overall acceptability which were named: (FSC,FMSCN,FBSCN,FMBSCN,FASCN,FMASCN.FGSCN , FMGSCN and RSCN).these results in agreement with [25] Fried products are appreciated everyone because of their improved palatability where consumers generally like eating foods with soft core and crispy surface. Frying is known as one of the oldest food cooking processes dating back as early as sixteen centuries B.C., being still widespread utilized today at both domestic and industrial scale, because of its ability to enhance flavor and texture of numerous foods. Food deep frying induces several changes in both chemical and physical properties of the different components, including protein denaturation, starch gelatinization, water vaporization and crust formation [26], [27] Fried foods are very tasty and hence popular in our meals. Frying of nuts is an alternative process to dry roasting, resulted in products with high added value. These products are the preferred snacks for exporting purposes. Frying against dry roasting of nuts protects the surface of the product against oxidation during storage by incorporating the frying oil with higher stability than that of the nut lipids.

Table 2a. Nutritional quality $\left(\% d w t^{*}\right)$ and mineral contents (ppm) of raw corn kernels.

\begin{tabular}{llll}
\hline Moisture & 13.7 & $\mathrm{Fe}$ & 44.23 \\
Protein & 7.17 & $\mathrm{Zn}$ & 63.75 \\
Fat & 5.6 & $\mathrm{Ca}$ & 528 \\
Ash & 2.85 & $\mathrm{Na}$ & 439.9 \\
Fiber & 2.41 & $\mathrm{Mg}$ & 939.3 \\
T.C** & 81.97 & $\mathrm{~K}$ & 2819 \\
Energy $406.9 \mathrm{kcal} / 100 \mathrm{~g}$ & & \\
\hline
\end{tabular}

dwt*: dry weight T.C ${ }^{* *}$ : total carbohydrate calculated by different

Table 2a showed Chemical composition (\%dwt) and minerals content (ppm) of raw corn kernels, Proximate composition shows moisture content was $13.7 \%$, protein, fat, ash, fiber and total carbohydrates contents were 7.17, 5.6, $2.85,2.41$ and $81.97 \%$ respectively, which was a mean energy value $406.9 \mathrm{Kcal}$. Concerning to the minerals content of raw corn kernels, it could be mentioned that $\mathrm{Fe}, \mathrm{Zn}, \mathrm{Ca}$, $\mathrm{Na}, \mathrm{Mg}$, and $\mathrm{K}$ contents were 44.23, 63.75, 52.8, 439.9,939.3 and2819 respectively. These results are in agreement with [28] who found that Proximate composition of ten maize varieties grown in NWFP, Pakistan shows moisture content in the range of $9.2-10.9 \%$, ash $(0.7-1.3 \%)$, fats $(3.21-7.71 \%)$, protein (7.71-14.60\%), crude fiber $(0.80-2.32 \%)$ and carbohydrates $(69.7-74.5 \%)$. The energy value of the grains of these varieties was determined in the range of 307.047$394.066 \mathrm{kcal} / 100 \mathrm{~g}$. In minerals the level of sodium is 540.30-620.41 ppm, K (2915-3471 ppm), Ca (410-590 ppm), $\mathrm{Fe}$ (38.02-56.14 ppm), Zn (37.05-52.4 ppm), Mg (985.2$1125.3 \mathrm{ppm})$.

Table 2b. Moisture content (\%) and nutritional quality (dwt \%**) of Commercial Corn Nut, raw corn kernels and corn nuts products which produced by different technological processes.

\begin{tabular}{lllllllll}
\hline \multirow{2}{*}{ Treatment } & \multirow{2}{*}{ Moisture (\%) } & \multicolumn{2}{l}{ Nutritional value (on dry weight) } & & & \\
\cline { 3 - 8 } & & Protein \% & Fat \% & Fiber \% & Ash \% & T.C * \% & Energy (kcal) \\
\hline CCN & 2.85 & 7.5 & 22.5 & 1.19 & 2.08 & 63.88 & 488.00 \\
RCS & 13.7 & 7.17 & 5.6 & 2.41 & 2.85 & 81.97 & 406.90 \\
FSCN & 3.30 & 6.70 & 14.60 & 2.26 & 1.30 & 75.14 & 458.75 \\
FMSCN & 2.40 & 6.75 & 16.00 & 2.07 & 1.43 & 73.75 & 466.00 \\
FBSCN & 3.50 & 6.20 & 16.60 & 2.13 & 1.55 & 73.52 & 468.00 \\
FMBSCN & 2.90 & 6.30 & 17.20 & 1.63 & 2.46 & 72.41 & 469.60 \\
FASCN & 6.10 & 6.36 & 17.56 & 2.02 & 2.55 & 71.51 & 469.50 \\
\hline
\end{tabular}




\begin{tabular}{lllllllll}
\hline \multirow{2}{*}{ Treatment } & \multirow{2}{*}{ Moisture (\%) } & \multicolumn{2}{l}{ Nutritional value (on dry weight) } & \multicolumn{1}{l}{} \\
\cline { 3 - 8 } & & Protein \% & Fat \% & Fiber \% & Ash \% & T.C * \% & Energy (kcal) \\
\hline FMASCN & 4.70 & 6.50 & 19.83 & 1.58 & 2.70 & 69.39 & 482.00 \\
FGSCN & 2.50 & 7.25 & 15.68 & 1.26 & 1.75 & 74.06 & 466.36 \\
FMGSCN & 2.40 & 7.30 & 19.88 & 2.18 & 2.60 & 68.04 & 480.30 \\
RSCN & 5.57 & 7.20 & 8.00 & 2.26 & 1.95 & 80.59 & 423.20 \\
\hline
\end{tabular}

Where:

T.C*: Total carbohydrate was calculated by difference. dwt**: dry weight

CCN: Commercial Corn Nut, RCK: Raw Corn kernels, FSCN: Fried Soaked d Corn nut, FMSCN: Fried Micro waved Soaked Corn nut, FBSCN: Fried Boiled Soaked Corn nut, FMBSCN: Fried Micro waved Boiled Soaked Corn nut, FASCN: Fried Autoclaved Soaked Corn nut,FMASCN: Fried Micro waved Autoclaved Soaked Corn nut ,FGSCN: Fried Germinated Soaked Corn nut, FMGSCN: Fried Micro waved germinated Soaked Corn nut, RSCN:Roasted Soaked Corn nut

Table $2 \mathrm{~b}$ Proximate analyses (moisture, protein, fat, fiber, ash and carbohydrate contents) were carried out on raw corn kernels (RCK), commercial corn nuts (as a control) and all acceptable corn nut products

(FSCN,FMSCN,FBSCN,FMBSCN,FASCN,FMASCN,FG SCN,FMGSC and RSCN), which have a mean a score value from 5 to 9 (neither like or dislike until like extremely) were shown in Table (1). Moisture content of raw corn kernels (RCK)was $13.7 \%$ which ranged from 2.5 to 6.1 and 2.4 to $4.7 \%$ dwt after ordinary and microwave roasting processes, respectively. It can be noticed that moisture content decreased significantly as a result of both ordinary and microwave roasting. Also, it's clear that the decrease caused by microwave roasting is more than that caused by ordinary roasting. These results are in agreement with those found by [29], [30], [31] who reported that roasting processes decreased moisture content of pea nut. Ash content of the control was $2.08 \%$. The processing methods resulted in decreasing ash content except that of RCK, FMBSCN, FASCN, FMASCN and FMGSCN which increased slightly than the commercial corn nut. The reduction in ash content might be due to the leaching out of both macro and micro elements into the soaking and cooking water. These results agreement with [32]. Also it can be observed that protein content of raw corn kernels (RCK) 7.17\% dwt, which was slightly increased to $7.20,7.25$ and $7.3 \% \mathrm{dwt}$ for RSCN,FGSCN,FMGSCN respectively as a result of using germination process before ordinary and microwave roasting processes, This result is similar with [33] who stated that there was increase in protein content of sprouted maize flour than raw maize flour. The nutritional value of native proteins is improved by heat treatments as they are converted to more digestive denatured forms as well as result into inactivation of heat labile enzymes such as lipoxygenase, trypsin inhibitor and urease [34]. As a result of using microwave roasting processes slightly increasing in protein content compared with using ordinary, the increase was significant by microwave roasting while it was not significant by ordinary roasting, these results are similar to those found by [31]. From the previous results it could be stated that roasting by microwave was better than ordinary roasting in maintenance of protein. Fat content amountented in 5.6\%, $8 \%, 22.5 \%$ and ranged from 14.6 to $19.88 \%$ dwt for raw corn kernels (RCK), roasted socked corn nut (RSCN), commercial corn nut $\mathrm{CCN}$ respectively (as a control) and among all acceptable fried corn nut products respectively. In general the results indicated that, fat content increased by roasting and specialty by using microwave roasting. On other hand, the increased fat content caused by microwave roasting is more than that caused by ordinary roasting may be due to the moisture decreasing by microwave was more than ordinary roasting. These results are in agreement with those found by [29], [31] who reported that there was an increase in crude oil of peanut after heat treatments, also microwave roasting increased fat content of peanut more than ordinary roasting. Fiber content showed to be higher in raw corn kernels (RCK) $2.41 \%$ dwt compared with the control (CCN) $1.19 \%$ dwt and all acceptable corn nut products which ranged from 1.63 to $2.26 \%$ dwt. these results were in parallel with [35] who depicted that the fiber content of raw and roasted maize was $1.58 \%$ and $0.82 \%$. The results also showed that raw corn kernels (RCK) contained total carbohydrate by about 81.97 d.wt, with slightly decrease (80.59) after roasting (RSCN). It ranged from 71.51 to 75.14 and 68.04 to $73.52 \%$ dwt. after ordinary and microwave frying roasting processes, respectively. It could be noticed that total carbohydrates content decreased by both ordinary and microwave roasting as compared to raw corn seed and the most decrease caused by microwave roasting, where treatments which were roasted by microwave had less carbohydrate content than that roasted by the ordinary method. These results are in agreement with those reported by [29], [31]. carbohydrate found to be higher in the raw maize than roasted maize, concerning the energy values of the raw corn kernels (RCK), roasted socked corn nut (RSCN) and commercial corn nut (CCN) was 406.9,423.2 and 488.00 Kcal, respectively. Meanwhile fried treatments resulted in the energy values ranged between 458.75-482.00 Kcal, the energy values of commercial corn nut was higher than those of raw, roasted, and fried treatment which was agreed with those of [35].

Table 3 showed minerals contents (ppm) of commercial corn nut, raw corn kernels and all corn nuts products which produced by different technological processes. Among all corn nuts products (FSCN, FMSCN, FBSCN, FMBSCN, FASCN, FMASCN, FGSCN, FMGSC and RSCN), the results showed that $\mathrm{Fe}, \mathrm{Zn}, \mathrm{Ca}, \mathrm{Na}, \mathrm{Mg}$, and $\mathrm{K}$ contents 
ranged from 20 to $44,35.12$ to $58.0,268.5$ to $528.5,160$ to $397,526.5$ to 861.6 and 1876 to $2550 \mathrm{ppm}$ respectively. Where the highest $\mathrm{Fe}, \mathrm{Zn}, \mathrm{Ca}$ and $\mathrm{Na}$ content were found in FM BSC, FBSC,FASC and FMASC treatments and the highest $\mathrm{Mg}$ and $\mathrm{K}$ content was found in FMSC treatment. Compared to raw corn kernels (RCK) and commercial corn nuts $(\mathrm{CCN})$, mineral contents were (44.23 and 29.52), (63.75 aND 59.36), (528 and 958), (439.9 and 300), (939.3 and 688.5) and (2819 and 1372.2) for $\mathrm{Fe}, \mathrm{Zn}, \mathrm{Ca}, \mathrm{Na}, \mathrm{Mg}$, and $\mathrm{K}$ respectively. From the obtained results it could be observed that raw corn kernels had the highest values of minerals contents which decreased after different processing methods (soaking, boiling, autoclaving .....etc). on other words among all corn nuts products a parallel decreasing was observed in minerals contents by both ordinary and microwave roasting as compared to raw corn kernels and the most decrease caused by ordinary roasting, where treatments by microwave had $\mathrm{Fe}, \mathrm{Na}, \mathrm{Mg}$, k contents more than that roasted by the ordinary processes and vs. versa in $\mathrm{Ca}$ and $\mathrm{Zn}$ contents. These results are in agreement with those [36], who reported that soaking of whole grains such as millet, maize, sorghum, rice, soybean, cowpea, and mung bean reduced iron and zinc contents in all grains, the effect may be due to the leaching of minerals in soaking water, and up to $40 \%$ of Fe content of sorghum grain may be lost as a result of soaking. Reduction after soaking may be attributed to leaching of iron and zinc ions into the soaking medium [37], [36] found that cooking processes affect mineral contents and their solubility and also the contents of other components that can affect mineral solubility. [39] found that, microwave roasting was more effective in maintenance peanut contents of $\mathrm{Mg}, \mathrm{Na}$ and $\mathrm{Fe}$, while ordinary roasting was better in maintenance $\mathrm{Ca}$, and they were equal in maintenance of $\mathrm{K}$ and $\mathrm{Zn}$.

Table 3. Minerals contents (ppm) of commercial corn nut, raw corn kernels and all corn nuts products which produced by different technological process (on dry weight).

\begin{tabular}{lllllll}
\hline Treatment & Fe & Zn & Ca & Na & Mg & K \\
\hline CCN & 29.52 & 59.36 & 958 & 300 & 688.5 & 1372.2 \\
RCK & 44.23 & 63.75 & 532 & 439.9 & 939.3 & 2819 \\
FSC & 23.26 & 43.99 & 293 & 265 & 763.7 & 2364.2 \\
FMSC & 22.2 & 35.12 & 268.5 & 388 & 861.6 & 2550 \\
FBSC & 38.8 & 58.0 & 456 & 248.5 & 639 & 2270 \\
FMBSC & 44.0 & 44.4 & 311.3 & 368 & 741 & 2428 \\
FASC & 28.96 & 43.28 & 528.5 & 340.8 & 526.5 & 2095 \\
FMASC & 27.86 & 37.4 & 400.9 & 397 & 560.5 & 2112 \\
FGSC & 33.67 & 52.0 & 520 & 251.5 & 646 & 2416 \\
FMGSC & 43.7 & 40.8 & 417.5 & 314 & 657 & 2465 \\
RSC & 20 & 39.2 & 505 & 160 & 814.5 & 1876 \\
\hline
\end{tabular}

where:

CCN: Commercial Corn Nut, RCK: Raw Corn kernels, FSC: Fried Soaked Corn nut, FMSC: Fried Micro waved Soaked Corn nut, FBSC: Fried Boiled Soaked Corn nut, FMBSC: Fried Micro waved Boiled Soaked Corn nut, FASC: Fried Autoclaved Soaked Corn nut FMASC: Fried Micro waved Autoclaved Soaked corn nut, FGSC: Fried Germinated Soaked Corn nut, FMGSC: Fried Micro waved Germinated soaked Corn, RSC: Roasted Soaked Corn nut.
Table 4. Amylose and amylopectin contents (\%) of raw corn kernels and corn nuts products which produced by different technological process (on dry weight)

\begin{tabular}{lll}
\hline Treatment & Amylose content & $\begin{array}{l}\text { *Amylo pectin } \\
\text { content }\end{array}$ \\
\hline RCK & 22.9 & 77.1 \\
FSCN & 18.17 & 81.83 \\
FMSCN & 16.67 & 83.33 \\
FBSCN & 19.28 & 80.71 \\
FMBSCN & 16.29 & 83.71 \\
FASCN & 18.54 & 81.46 \\
FMASCN & 17.79 & 82.21 \\
FGSCN & 20.79 & 79.21 \\
FMGSCN & 18.16 & 81.84 \\
RSCN & 21.54 & 78.46 \\
\hline
\end{tabular}

Where:* was calculated by (100- Amylose content \%).

RCK: Raw corn kernels, FSCN: Fried Soaked Corn nut, FMSCN: Fried Micro waved Soaked Corn nut, FBSCN: Fried Boiled Soaked Corn nut, FMBSCN: Fried Micro waved Boiled Soaked Corn nut, FASCN: Fried Autoclaved Soaked Corn nut, FMASCN: Fried Micro waved Autoclaved Soaked Corn nut, FGSCN: Fried Germinated Soaked Corn nut, FMGSCN: Fried Micro waved Germinated Soaked Corn nut, RSCN: Roasted Soaked Corn nut

Table 4 shows amylose and amylopectin content of raw corn kernels and all corn nut products which produced by different technological processes. From the results, raw corn kernels kernels had amylose and amylopectin contents of 22.9 and $77.1 \%$ respectively. After processing a decrease in amylose content was found among all corn nut products which ranged from 16.29 to $21.54 \%$ compared to raw corn kernels $(22.9 \%))$. The highest amylose content was found in raw corn kernels (RCK) 22.9\% followed by roasted corn nut (RCS) $21.54 \%$.while the highest amylo pectin 83.71, 83.33 and $82.21 \%$ was found in FMBSC, FMSC and FMASC treatments respectively. This results are in agreement with [40], who reported that maize is predominantly starch (60-75\%), in the form of amylose and amylopectin. The ratio of amylose to amylopectin is ordinarily $25 / 75$, although this ratio can be altered by genetic modifications. In fact, amylose, as a percentage of starch in different genotypes of maize, ranged from $0 \%$ to $73 \%$ Also, the amylose content also similarly decreased by frying [41], reported that addition of cooking oil considerably lowered the net RS content. The FFA in the oil may form an inclusion complex with the amylose helix thereby decreasing the content of amylose available for retrogradation and subsequent RS formation. [41], [42] also showed decrease in RS content by frying. [43] reported that $\alpha$-Amylase activity is also increased during germination of cereals, especially sorghum and millet. This enzyme hydrolyzes amylose and amylopectin to dextrin's and maltose, while simultaneously enhancing their energy and nutrient densities. [44] found a decrease in amylose content of fermented sorghum. 
Table 5. Peroxide \& Acid values of all corn nut products during storage period (from zero time up to 10 weeks at room temperature $25 \pm 2{ }^{\circ} \mathrm{C}$ ).

\begin{tabular}{|c|c|c|c|c|c|c|c|c|c|c|c|c|}
\hline \multirow{2}{*}{ Treatment } & \multicolumn{6}{|c|}{ P.V ( meq/ kg oil $))^{*}$} & \multicolumn{6}{|c|}{ A.V (mg/KOH/g oil)** } \\
\hline & Zero & 2 & 4 & 6 & 8 & 10 & Zero & 2 & 4 & 6 & 8 & 10 \\
\hline FSCN & 0.97 & 1.76 & 2.05 & 4.99 & 7.57 & 12.45 & 0.11 & 0.26 & 0.3 & 0.38 & 0.72 & 1.15 \\
\hline FMSCN & 1.03 & 2.99 & 4.3 & 5.13 & 7.4 & 14.0 & 0.10 & 0.30 & 0.38 & 0.48 & 0.9 & 1.22 \\
\hline FBSCN & 1.2 & 3.22 & 3.34 & 3.8 & 4.0 & 11.0 & 0.09 & 0.19 & 0.2 & 0.45 & 0.8 & 1.09 \\
\hline FMBSCN & 1.1 & 3.26 & 3.9 & 4.26 & 7.78 & 14.3 & 0.09 & 0.15 & 0.255 & 0.7 & 1.0 & 1.25 \\
\hline FASCN & 0.3 & 1.3 & 1.8 & 2.7 & 5.2 & 9.1 & 0.08 & 0.26 & 0.39 & 0.5 & 0.72 & 1.0 \\
\hline FMASCN & 1.5 & 1.56 & 2.6 & 3.04 & 3.8 & 12.0 & 0.95 & 0.27 & 0.56 & 0.61 & 0.75 & 1.1 \\
\hline FGSCN & 0.56 & 1.34 & 1.75 & 2.44 & 2.59 & 4.55 & 0.12 & 0.4 & 0.43 & 0.47 & 0.52 & 0.53 \\
\hline FMGSCN & 0.46 & 1.21 & 1.65 & 1.7 & 2.7 & 7.73 & 0.11 & 0.32 & 0.35 & 0.42 & 0.56 & 0.87 \\
\hline $\mathrm{RSC}$ & 0.87 & 2.05 & 3.26 & 4.00 & 8.2 & 16.3 & 0.15 & 0.52 & 0.57 & 0.62 & 0.85 & 1.3 \\
\hline
\end{tabular}

* P.V: peroxide value ** A.V: Acid value

RCS: Raw Corn seeds, FSCN: Fried Soaked Corn nut, FMSCN: Fried Micro waved Soaked Corn nut, FBSCN: Fried Boiled Soaked Corn nut, FMBSCNN: Fried Micro waved Boiled Soaked Corn nut, FASCN: Fried Autoclaved Soaked Corn nut, FMASCN: Fried Micro waved Autoclaved Soaked corn nut, FGSCN: Fried Germination Soaked Corn nut, FMGSCN: Fried Micro waved Germinated Soaked Corn nut, RSCN: Roasted Soaked Corn nut.

In table 5 the results showed peroxide and acid values at zero time up to 10 weeks (storage periods) for all corn nut products at room temperature.the data reflected that at zero time peroxide and acid values ranged from 0.46 to $1.2 \mathrm{meq} /$ $\mathrm{kg}$ fat and 0.08 to $0.15(\mathrm{mg} / \mathrm{KOH} / \mathrm{g}$ oil) for all corn nut products. After 2 weeks. Minimum slight increasing was observed in both peroxide and acid values which was reached to it ś maximum value 4.55 to $16.3 \mathrm{meq} / \mathrm{kg}$ and 0.53 to 1.3 (mg/KOH/g oil) after 10 weeks for all corn nut products. Where RSC recorded the highest increasing in peroxide and acid values $16.3 \mathrm{meq} / \mathrm{kg}$ and $1.3 \mathrm{mg} / \mathrm{KOH} / \mathrm{g}$ oil respectively followed by FMBSCN, FMSCN and FSCN treatments which recorded peroxide and acid values14.3, 14.0, $12.45 \mathrm{meq} / \mathrm{kg}$ fat and $(1.25,1.22$ and 1.15$) \mathrm{mg} / \mathrm{KOH} / \mathrm{g}$ oil respectively and FGSCN, FMGSCN treatments were recorded the lowest peroxide and acid values 4.55, 7.73 and $0.53,0.87$ ( $\mathrm{mg} / \mathrm{KOH} / \mathrm{g}$ oil) respectively. From the results it must be observed that all micro waved corn nuts products had higher peroxide and acid values than the ordinary ones may be due to it ś higher fat contents (table 2-b). In turn, peroxide and acid values were increased and the corn nut products deteriorated earlier, first RSC, Micro waved corn nuts at least ordinary corn nut products which recorded peroxide value more than $10 \mathrm{meq} / \mathrm{kg}$ fat and acid value more than 1 (mg/KOH/g oil) except FGSCN , FMGSCN treatments which recorded a peroxide value less than $10 \mathrm{meq} / \mathrm{kg}$ fat and acid value less $1(\mathrm{mg} / \mathrm{KOH} / \mathrm{g}$ oil) respectively over storage period (from zero time up to 10 weeks at room temperature $25 \pm 2{ }^{\circ} \mathrm{C}$ ). this results in agreement with [24] If the acid value is less than 1 , the oil is safe, and if the value is more than 1, the oil has gone rancid. [45] ,the codex Alimentarius commission on 1982 stipulated a permitted maximum peroxide level of not more than $10 \mathrm{meq} \mathrm{meq} / \mathrm{kg}$ oil. [23] if the peroxide value is less than 5 , the oil is safe, between 510 , the oil is usable and not preservable, and more than 10 , the oil is unusable. The best test for autoxidation (oxidative rancidity) is determination of the peroxide value (PV) [46]. The previous results are in agreement with those reported by [47], [31], who indicated that ordinary roasting process raised acid and peroxide values of peanut oil. On the other hand, the previous results were agreement with [48], who found that peroxide values of microwave heated lipids were approximately $2 \%$ higher than those of traditional heated lipids.

\section{Conclusions}

In general moisture, fiber and carbohydrate contents were decreased while protein, fat and ash contents were increased by microwave compared to ordinary methods. Energy value was lower in all corn nuts products than commercial corn nut. $\mathrm{Fe}, \mathrm{Na}, \mathrm{Mg}$ and $\mathrm{K}$ contents recorded an increase by microwave compared with ordinary methods. The shelf life ranged from 8 to 1o weeks for all corn nuts products. Where, Fried Germination Soaked Corn nut (FGSCN) and Fried Microwave Germinated Soaked Corn nut (FMGSCN) treatments were recorded the lowest peroxide and acid values.

\section{References}

[1] Schenck, F. W. 1991. Corn and corn products. In Encyclopedia of Food Science and Technology (Y. H. Hui, ed.) pp. 482-490, John Wiley \& Sons, New York, NY.

[2] USDA/FAS] United States Department of Agriculture and Foreign Agricultural Service. 2008. Corn 2008: production, supply, demand database. Available from: http://www.pecad.fas.usda.gov/cropexplorer/. Accessed Nov 2009.

[3] Alexander RJ. 1987. Corn dry milling: processes, products, and applications. In: WatsonSA, RamstadPE, editors. Corn: Chemistry and Technology. St. Paul, Minn.: Am Assoc Cereal Chem. p 351-76.

[4] Brown, WL, Bressani R, Glover DV, Hallauer AR, Johnson VA, Qualset CO. 1988. Quality-protein maize: report of an ad hoc panel of the advisory committee on technology innovation, Board on Science and Technology for International Development, National Research Council, in cooperation with the Board on Agriculture, National Research Council. Washington, D. C.: National Academy Press.

[5] [FAO] Food and Agricultural Organization of the United Nations. 1992. Maize in human nutrition. Available from: http://www.fao.org/docrep/T0395E/T0395E00.htm\#Contents. Accessed Aug and Sept 2009. 
[6] James, K.; Butts, C. A.; Hardacre, A. K.; Koolaard, J. P.; Clark, S. M.; and Scott, M. F.; (2004). The effect of drying temperature on the nutrition quality of new Zeaaland -grown maize or growing rats. J. Sci. Food Agric., 84, 147-154.

[7] USDA. NNDB United States Department of Agriculture. 2009. National nutrient database for standard reference. Available from:

http://www.nal.usda.gov/fnic/foodcomp/search/. Accessed Sept and Oct 2009

[8] Afify AMR, El-Beltagi HS, Abd El-Salam SM, Omran AA (2011a). Bioavailability of iron, zinc, phytate and phytase activity during soaking and germination of white sorghum varieties. PLoS ONE 6 (10):25512, 1-7.

[9] Afify AMR, El-Beltagi HS, Abd El-Salam SM, Omran AA (2012a). Biochemical changes in phenols, flavonoids, tannins, vitamin $\mathrm{E}, \beta$-carotene and antioxidant activity during soaking of three white sorghum varieties. Asian Pac J Trop Biomed 2 (3):203-209.

[10] Afify AMR, El-Beltagi HS, Abd El-Salam SM, Omran AA (2012b). Protein solubility, digestibility and fractionation after germination of sorghum varieties. PLoS ONE 7 (2):31154, 16.

[11] Kayodé APP (2006). Diversity, Users' Perception and Food Processing of Sorghum: Implications for Dietary Iron and Zinc Supply. Ph. D. Thesis, Wageningen Univ., Netherlands, Wageningen, $151 \mathrm{p}$.

[12] Steiner T, Mosenthin R, Zimmermann B, Greiner R, Roth S (2007). Distribution of total phosphorus, phytate phosphorus and phytase activity in legume seeds, cereals and cereal byproducts as influenced by harvest year and cultivar. Anim Feed Sci Tech 133:320-334.

[13] Walker, G. J., 1979. CSIRO Information Service, Australia

[14] Aremu, M. O., Y. E. Olayioye and P. P. Ikokoh, 2009. Effects of processing on nutritional quality of Kersting's groundnut (Kerstingiella geocarpa L.) seed flours. J. Chem. Soc. Nig., 34 (2): 140-149.

[15] Rosina, L F and Isabel, M C (1996): Effect of continuous flow microwave treatment on chemical and microbioiogical characteristics of milk. Z Lebensm Unters Forsch., 202: 1518.

[16] Alhekail, Z O (2001): Electromagnetic radiation from microwave ovens. J. Radiol Port., 21 (3): 251-8.

[17] Adelakun, O. E., Adejuyitan, J. A.,Olajide, J. O and Alabi, B. $\mathrm{K}$ (2005). Effect of soybean substitution on some physical, compositional and sensory properties of kokoro (a local maize snack).Eur Food Res Techol. 220: 79-82.

[18] Tarek, A. E. (2002). Nutritional composition and antinutritional factors of chickpeas (Cicer arietinum L.) undergoing different cooking methods and germination Plant Foods for Human Nutrition 57: 83-97.

[19] Ijarotimi O S, Oluwalana IB, and Ogunedojutimi MO (2012).Nutrient composition, functional, sensory and microbial status of popcorn- based complementary foods enriched with cashew nut flour.AJFAND ONE 12 (5): 64246445 .

[20] AOAC (2000). Official Methods of Analysis of the Association of Official Analytical Chemists, 17th edn (ed. by
W. Horwitz). Washington, DC.

[21] James, C. S. (1995). Analytical chemistry of foods (1st ed.). London: Blackie Academic\& ProfessionalC 2002 Kluwer Academic Publishers. Printed in the Netherlands

[22] Juliano BO (1971). A simplified assay for milled rice amylose. Cereal Sci Today 16 (11): 334-339.

[23] Pomeranz, Y. (1994). Food Analysis: Theory and Practice. Chapman \& Hall Inc. New York P. 717.

[24] Sanchez M, Muniz FJ. 2006. Oils and fat: Changes due to culinary and industrial processes. Int $\mathrm{J}$ Vitam Nutr Res 76: 230.

[25] Moyano PC, Pedreschi F (2006) Kinetics of oil uptake during frying of potato slices: effect of pre-treatments. LWT - Food Science and Technology 39: 285.

[26] Mallikarjunan P, Chinnan MS, Balasubramaniam VM, Phillips RD (1997) Edible coating for deep-fat frying of starchy products. LWT-Food Science and Technology 30: 709-714. 3.

[27] Rimac-Brncic S, Lelas V, Rade D, Simundic B (2004) Decreasing of oil absorption in potato strips during deep fat frying. J Food Eng 64: 237-241.

[28] Ikram U., Muhammad A. and Farooqi, A (2010). Chemical and Nutritional Properties of Some Maize (Zea mays L.) Varieties Grown in NWFP, Pakistan. Pakistan Journal of Nutrition 9 (11): 1113-1117.

[29] Abayomi, P; Isaac, A and Ayodele, O (2002): Effects of processing conditions and packaging materials on the quality attributes of dry-roasted peanuts. J. Food Sci. Agric., 82: 1465-1471.

[30] Sanders, T. H; Hendrix, K;Raush, T D and KatzmTA (2002):Effect of microwave energy on blanch ability, shelf life and roast quality of peanut. Am. Peanuts Research Edu. Soc. Pro., 34: 112.

[31] Adegoke, G O; Falade, K O and Babalola, O C (2004): Control of lipid oxidation and fungal spoilage of roasted peanut (Arachis hypogaea) using the spice Aframomum danielli. Food. Agric. Environment., 2 (1): 128-131.

[32] Myrene R. (2013). D'souza. Effect of Traditional processing Methods on Nutritional Quality of Field Bean. Adv. Biores. 4: 29-33.

[33] Pandhare RB, Sangameswaran B, Mohite PB, Khanage SG. (2012). Attenuating effect of Sesbania sesban (L) Merr. extract on neuropathic pain in streptozotocin-induced diabetic rats: an evidence of neuroprotective effects. Phytopharmacol. 2: 190-201.

[34] Mubarak AE. (2005). Nutritional composition and antinutritional factors of mungbean seeds (Phaseolus aureus) as affected by some home traditional processes. J. Food Chem. 89: 489-495.

[35] Adetunde OT, Oluseyi TO, Olayinka KO, Oyeyiola AO, Alo B. (2012).Effects of Roasting on the Proximate Composition and Levels of Polycyclic Aromatic Hydrocarbons in Some Roasted Nigerian Delicacies. J. Emerg. Trend. Eng. Appl. Sc.; 3: $857-862$.

[36] Lestienne, I., Icard-Vernière, C., Mouquet, C., Picq, C., \& Trèche,S. (2005). Effects of soaking whole cereal and legume seeds on iron, zinc and phytate contents. Food Chemistry, 89, 421-425. 
[37] Saharan K, Khetarpaul N, Bishnoi S (2001). HClextractability of minerals from rice bean and faba bean: Influence of domestic processing methods. Innovative Food Sci Emerging Tech 2 (4): 323-325.

[38] Viadel B, Barbera R, Farre R (2006). Uptake and retention of calcium, iron, and zinc from raw legumes and the effect of cooking on lentils in Caco-2 cells. Nutr Res 26:591-596.

[39] El-Badrawy, E. E.Y.; El-Zainy, A. R. M.; Shalaby, A. O. and El-Sayed, N. Y. (2007). effect of microwave roasting on chemical composition of peanut seeds and comparing with the ordinary roasting process. Home Economics Dept., Faculty of Specific Education, Mansoura University, Egypt., pp. 939956

[40] Creech RG, Alexander DE. 1978. Breeding for industrial and nutritional quality in maize. In: WaldenDB, editor. Maize breeding and genetics. New York: John Wiley \& Sons. p 249 264.

[41] Mahadevamma S, Tharanthan RN. (2004). Processing of legumes: resistant starch and dietary fiber contents. J Food Qual. 27:289-303.

[42] Platel K, Shurpalekar KS. (1994). Resistant starch of Indian foods. Plant Foods Hum Nutr.; 45: 91-95.
[43] Hotz C, Gibson RS (2007). Traditional food-processing and preparation practices to enhance the bioavailability of micronutrients in plant-based diets. J Nutr 137: 1097-1100

[44] Osungbaro TO, Jimoh D, Osundeyi E (2010). Functional and pasting properties of Composite Cassava-Sorghum flour meals. Agric Biol J North Am 1 (4):715-720.

[45] Uluata, S., and Özdemir, N. (2012). Antioxidant activities and oxidative stabilities of some unconventional oilseeds. Journal of the American Oil Chemist Society, 89,551 -559.

[46] AFSHAN, K., AZIZ, S., MEHWISH, I., ABDULLAH, R., MAHWISH A., RASHID, F., RAUF F. S. AND SHAGUFTA, N. (2015). Investigating changes and effect of peroxide values in cooking oils subject to light and heat. KALEEM ET AL FUUAST J. BIOL., 5 (2): 191-196.

[47] Seda, H A; Moram, G S; Mohamoud, A A and El-Niely, H F G (2001): Chemical and biological changes of peanut Kernels (Arachis hypogaea) lipids by irradiation or roasting process. Annals Agric. Sci. Ain Shams Univ., Cairo, 46 (1): 233-251.

[48] Farag, R S (1994): Influence of microwave and conventional heating on the quality of lipids in model and food systems. Fett-Wissenschft-Technologie, 96: 213. 